\title{
Clinical and Experimental Study of the Toxic Neuropsychiatric Effects of Formaldehyde Exposure: Has Garlic a Protective Role?
}

\author{
Wafaa Ibrahim Soliman'1*, Nashwa Mohamad Mohamad Shalaby', Hisham Mohammed Al-sayed², \\ Mona Hamed Ibrahim ${ }^{3}$

\footnotetext{
${ }^{1}$ Department of Forensic Medicine and Clinical Toxicology, Faculty of Medicine, Zagazig University, Zagazig, Egypt

${ }^{2}$ Department of Neuropsychiatric, Faculty of Medicine, Benha University, Benha, Egypt

${ }^{3}$ Department of Community, Environmental and Occupational Medicine, Faculty of Medicine, Zagazig University, Zagazig, Egypt

Email: `Sery1968@yahoo.com
}

How to cite this paper: Soliman, W.I., Shalaby, N.M.M., Al-sayed, H.M. and Ibrahim, M.H. (2018) Clinical and Experimental study of the toxic Neuropsychiatric effects of formaldehyde exposure: Has garlic a protective role? Occupational Diseases and Environmental Medicine, 6, 1-22. https://doi.org/10.4236/odem.2018.61001

Received: December 20, 2017

Accepted: January 27, 2018

Published: January 30, 2018

Copyright $\odot 2018$ by authors and Scientific Research Publishing Inc. This work is licensed under the Creative Commons Attribution International License (CC BY 4.0).

http://creativecommons.org/licenses/by/4.0/

\begin{abstract}
Background: The central nervous system is one of the most important systems affected by formaldehyde (FA). Aim of Work: This study was designed to assess its toxic neuropsychiatric effects both clinically and experimentally and the protective effects of garlic. Methods: Clinically: 20 workers in the gross anatomy laboratory and 20 libertarians underwent a standardized clinical assessment including medical, neurological and psychiatric examination. Experimental: 40 male rats were divided randomly into four groups. Group I is control group. Group II received $10 \mathrm{mg} / \mathrm{kg}$ of FA intraperitoneally once daily for 14 days. Group III was treated with fresh garlic juice $(1 \mathrm{ml} / 100 \mathrm{~g}$ body weight) once daily by oral gavage for 14 days. Groups VI received fresh garlic juice plus formaldehyde daily for 14 days. At the end of the experiment, the rats' brains were obtained for histological examination and biochemical analysis. Results: Clinical and psychiatric profile of FA exposed persons' revealed cognitive impaired, anxious and depressed persons. There were hostile persons with more hostility toward outside. Experimentally, hippocampal and frontal superoxide dismutase and reduced glutathione showed highly significant decrease while malondialdehyde and nitric oxide level showed highly significant increase in formaldehyde treated group when compared with control group. Also histopathological changes in the hippocampal and frontal cortices by light microscope revealed many distorted cells with deeply stained shrunked nuclei and cytoplasm was surrounded by vacuolated pale areas in FA exposed group. Minimization of biochemical and histopathological changes were observed in combined formaldehyde and garlic treated group.
\end{abstract}


Conclusion: The profiles of personality arouse dangerous affairs about the toxic impact of FA on persons, family, and society. Formaldehyde-induced neuronal damage, oxidative stress and lipid peroxidation in brain were minimized by addition of garlic.

\section{Keywords}

Formaldehyde, Neurotoxicity, Neuropsychiatry, Garlic, Oxidative Stress, Cognitive Impairment

\section{Introduction}

Formaldehyde (FA) is a ubiquitous chemical agent. It is a part of our general outdoor environment. Also, it is a part of our indoor working and residential environment. It is believed that whole civilized population is exposed to formaldehyde [1] [2]. Formaldehyde, which is an environmental pollutant, is generated in substantial amounts in the human body during normal metabolism [3]. The common commercial form of formaldehyde (formalin) contains 37\% - 50\% formaldehyde in water by weight and is stabilized against polymerization by the addition of $1 \%-15 \%$ methanol. Formaldehyde is also commercially available as solid containing 91\% - 95\% formaldehyde and 5\% - 9\% water (paraformaldehyde) [4]. Some of the commonly used products containing either formaldehyde or formaldehyde-releasing substances are used as construction materials, fertilizers, fumigants, polish, cosmetics, paints, cleaning agents, and toiletries [5] [6] [7].

In addition, FA can be produced as burning product of wood, coal, tobacco, natural gas, and kerosene [6] [8]. Also, foods as coffee, codfish, meat, poultry, and maple syrup naturally contain formaldehyde [6] [9].

In the medical field, FA is often utilized in laboratories. Fixation and long-run storage of organs and cadavers are achieved by FA. Also, it's utilized in tissue fixation stage in microscopic anatomy and pathology laboratories. Additionally, it's usually utilized in dental coating materials, within the treatment of cases with persistent urinary tract infection and as a protecting agent for a few medicines. Moreover, dialysis solutions typically contain formalin [10] [11] [12]. The permissible exposure limits for formaldehyde in all workplaces which were estimated by the National Institute for Occupational Safety and Health (NIOSH) are in the range of $1.5-3 \mathrm{mg} / \mathrm{m}^{3}$. However, many studies have proved that the FA levels in occupational sites are commonly exceeding that [13] [14].

Formaldehyde has a high propensity for reacting with RNA, DNA, and protein, which leads to many health hazard [15] [16]. It has toxic effects on the skin, eyes, respiratory tract, urogenital system, and the nervous system [4] [17] [18]. Exposure to FA has been reported to cause neurotoxicity in both humans and animals and the extent of damage depends on the dose and the duration of the exposure [19] [20] [21] [22]. Garlic (Allium sativum), that could be a member of 
the family Liliaceae, has been used as a medicating ingredient with physiological potential for an extended time. Garlic contains sulfur, phosphorus, potassium and zinc ions, moderate amounts of selenium, vitamin $\mathrm{C}$, antiophthalmic factor and smaller amounts of calcium, magnesium, sodium, iron, B-complex vitamins and allicin. The inhibitor effects of garlic because of allicin, that entice free radicals [23] [24]. In addition, the sulfur has anti-mutagenic and anti-carcinogenic effects [25].

This study was designed to assess the toxic neuropsychiatric effects of FA clinically and experimentally and the protective effects of garlic (as an antioxidant) against the neurotoxicity-induced by FA in rats.

\section{Methods}

This study consisted of two parts:

1) Clinical comparative cross section study

2) Experimental study

\subsection{Clinical Comparative Cross Section Study}

The study was conducted in Zagazig University, Faculty of Medicine in the duration from 1st of October 2015 to 31th of December 2015. Twenty workers (employees and instructors) in the gross anatomy laboratory (lab), for more than one year, and 20 librarians were included in this study.

The inclusion criteria included: Adults' $\geq 21$ and $\leq 50$ years old spent at least one year working regularly in gross anatomy lab or library with normal routine laboratory investigation such as blood sugar, lipid profile (cholesterol, triglyceride, HDL and LDL), kidney function test and liver function test.

- Absence of any gross abnormality in medical examination with normal pulse, blood pressure, heart rate and temperature.

- Chest, heart, abdomen and neurological examinations are clinically free.

- No manifestations of epidemic or endemic infections.

The exclusion criteria included substance abuse, hepatic or renal disease, malignant tumor, surgery within 6 month, neurodegenerative disorder, any medical disorder such as hypertension, diabetes and any previous history or present history of psychiatric disorders.

This study was carried out within the ethics of scientific research and an ethical approval for this study was obtained from the Institutional Review Board of Zagazig University, faculty of medicine, the approval number ZU-IRB \#4045-2-9-2015. All subjects were fully informed about the nature and objectives of this study and a written informed consent was taken from them. All data are confidential and used only for the research purpose and they were not exposed to any harm or risk.

All participants underwent:

- A standardized clinical assessment: including medical, neurological and psychiatric examination. 
- Mini-Mental state examinations [26].

- Hostility Quantity and Hostility Direction Questionnaire (H-Q-H-D) [27]. Arabic version [28].

- Middlesex hospital questionnaire (MHQ) [29]. Arabic version [30].

\subsection{Experimental}

The study was conducted using adult albino rats. Females' hormones have an effect on the results [31] so adult male rats were used for this study. The rats were maintained according to the guidelines of the Institutional Animal Ethics Committee. They were kept in polypropylene cages at the temperature $24^{\circ} \mathrm{C}, 45 \%$ relative humidity, and 12 hours light and dark cycles with free access to drinking water and food. Possible confounding factors in this study were the weight, age, environment, water and food of the rat. However, these conditions were identical for all of the rats and we controlled any confounding factors. The rats age range (6 - 8) weeks and their weights were (200 - 250) grams.

A total of 40 male rats were divided randomly into four groups. Group I (control) received an intraperitoneal (ip) injection of normal saline every day. The rats in Group II received $10 \mathrm{mg} / \mathrm{kg}$ of formaldehyde ip once daily for 14 days concentration $36.6 \%$ to $38 \%$ in water [32]. Group III: rats were treated with fresh garlic juice ( $1 \mathrm{ml} / 100 \mathrm{~g} /$ Body weights) once a day by oral gavage for 14 days [33]. Groups VI was received oral gavage of fresh garlic juice $(1 \mathrm{ml} / 100 \mathrm{~g} /$ Body weights) plus ip formaldehyde $(10 \mathrm{mg} / \mathrm{kg}$ ) daily for 14 days.

At the end of the two weeks experimental period, all of the rats were scarified and their brains (frontal and hippocampus) were obtained for histological examination and biochemical analysis.

\subsubsection{Rationale of Using Garlic Juice}

Many people cannot freely eat fresh raw garlic (FRG) because of its intense taste and smell even though they know that garlic is good for their health. In addition, the consumption of FRG is often associated with several health hazards, such as stomach and digestion problems [34]. Therefore, different formulations of garlic preparation including aged garlic extract (AGE), dehydrated garlic powder, garlic oil and garlic oil macerate, etc. were developed [35].

So, we decided to use garlic juice in this study for easy preparation, administration and to avoid any gastric problem to rats.

\subsubsection{Preparation of Garlic Juice}

To prepare garlic juice, garlic bulbs were separated, peeled and washed with distilled water. After drying in a shed, the clean garlic bulbs were crushed with an electric grinder and the extract was decanted carefully through muslin cloth [36].

\section{- Brain tissue Sampling}

At the end of the study, the rats were euthanized by decapitation and their brains (frontal and hippocampus) were taken. Each brain was divided into two parts; one was flash frozen in liquid $\mathrm{N} 2$ and stored at $-80^{\circ} \mathrm{C}$ for later use in 
measures of malondialdehyde (MDA) and reduced glutathione (GSH) contents, superoxide dismutase (SOD) activities and nitric oxide (NO) level. The other part was processed for histologic examination.

\section{- Biochemical Study}

Reduced glutathione (GSH) contents in the brain were assessed according to the method of Ahmed et al. [37] based on a 5,5'-dithiobis-2-nitrobenzoic acid (DTNB) reaction. Briefly, $0.1 \mathrm{~g}$ tissue was homogenized in $1 \mathrm{ml}$ phosphate buffer $(\mathrm{pH}=8)$ at $4{ }^{\circ} \mathrm{C}$. An aliquot $(0.5 \mathrm{ml}$ of homogenate) was mixed with $0.5 \mathrm{ml} 10 \%$ TCA in $5 \mathrm{ml}$ EDTA solution and the mixture was then centrifuged at $2000 \times \mathrm{g}$ for $5 \mathrm{~min}$. The supernatant generated was used for the determination of GSH at 412 $\mathrm{nm}$ in the spectrophotometer. As total protein content was needed for calculation of GSH content in the tissues, this parameter was determined using a Biocon Diagnostic kit (GmbH, Vohl-Marienhagen, Germany). All data were expressed as nmol GSH/mg protein.

Brain Tissue SOD activity was measured according to the method of Nishikimi et al. [38]. An aliquot of splenic or thymic homogenate supernatant $(50 \mu \mathrm{l})$ was combined to $100 \mu$ l sodium pyrophosphate buffer ( $\mathrm{pH} 8.3$ ), $0.1 \mathrm{ml}$ of $0.3 \mathrm{M}$ nitrobluetetrazolium, and $0.1 \mathrm{ml}$ of $780 \mu \mathrm{M} \mathrm{NADH}$; after mixing, $10 \mu \mathrm{l}$ of 186 $\mu \mathrm{M}$ phenazinemethosulfate (PMS) solution was added to initiate the reaction. Because SOD enzyme inhibits PMS-mediated reduction of nitrobluetetrazolium, the rate of increase in absorbance (measured at $560 \mathrm{~nm}$ ) was used to reflect SOD content in the sample. All data were ultimately reported as $\mathrm{U} / \mathrm{g}$ tissue, with $1 \mathrm{U}=$ the amount of enzyme required to produce a $50 \%$ inhibition in NBT reduction.

Brain contents of MDA (indices of lipid peroxidation) were determined spectrophotometrically using a commercial kit (DokkiBiodiagnostic, Giza, Egypt). Briefly, an aliquot of tissue extract supernatant was mixed with $1 \mathrm{ml} \mathrm{5 \%}$ trichloroacetic acid and then centrifuged at $2500 \times \mathrm{g}$ for 10 minutes. Supernatant $(0.2$ $\mathrm{ml}$ ) was transferred to a test tube and then $0.2 \mathrm{ml}$ of $8.1 \%$ sodium dodecyl sulfate (SDS), $1.5 \mathrm{ml}$ of $30 \%$ acetic acid $(\mathrm{pH}=3.5)$ and $1.5 \mathrm{ml}$ of $0.8 \%$ thiobarbituric acid (TBA) were added. The tube was mixed, covered with glass beads, heated in water bath (at $95^{\circ} \mathrm{C}$ ) for 30 minutes and then cooled. After centrifugation $(4000 \times \mathrm{g}, 10 \mathrm{~min})$, the supernatant was isolated and absorbance of the pink color was measured at $532 \mathrm{~nm}$ in Model UVD-2950 scanning spectrophotometer (Labomed Inc., Los Angeles, CA). A standard curve was generated using 1,1,3,3-tetraethoxypropane; from this curve, MDA levels in each sample were extrapolated. All data were expressed as nmol MDA/g tissue processed, Ohkawa et al. [39].

Nitric oxide (NO) was determined using colorimetric assay where nitrate is converted to nitrite via nitrate reductase. Griess reagent then act to convert nitrite to a deep purple azo compound that can be determined using spectrophotometer [40].

\section{- Histopathological Examinations}

Brain tissues were embedded in paraffin wax and cut into sections $(3-5 \mu \mathrm{m}$ 
thickness) and stained with haematoxylin and eosin ( $\mathrm{H}$ and $\mathrm{E})$. Examination of the stained tissue sections was done by a pathologist, who was blinded to the protocol of the study.

\section{- Statistical Analysis}

Continuous variables are reported as means with SD if normally distributed, an independent $t$ test used for comparing two groups and An ANOVA with Tukey Kramer's test used for multiple comparisons. Qualitative data were represented as frequencies and percentages, Chi-square test $\left(\chi^{2}\right)$ and fisher exact test were used for comparing groups. The test results were considered significant when $\mathrm{p}$-value $<0.05$ and all $\mathrm{p}$ values were two-tailed. Data were analyzed using Statistical Package of Social Science (SPSS), software version 16.0 [41].

\section{Results}

\subsection{Clinical Study}

Regarding sociodemographic characteristics, both FA-exposed persons (gross anatomy Lab. workers) and control group (librarians) were matched for age, gender, educational level and marital status (Table 1).

Clinical assessment of both groups revealed that the most common physical symptom reported by FA-exposed group was: easy fatigability, headache, excessive sleep, anorexia, eye irritation, excessive lacrimation, chest tightness and cough.

Mini-mental state examination in the present study revealed that, FA-exposed persons were more cognitively impaired than control group $(24.95 \pm 3.4$ and $27.2 \pm 2.6 \mathrm{p}=0.03$ ) respectively (Figure 1 ).

Middlesex hospital questionnaire (MHQ) of studied groups had shown a statistically significant difference between the two groups. FA exposed group suffered from more anxiety, somatization and depression (Table 2).

Hostility Direction and Hostility Quantity Questionnaire (HDHQ) revealed that FA exposed group was more hostile than control group. The direction of hostility in FA exposed group was more toward outside than control group (Table 3).

\subsection{Experimental Study}

\subsubsection{Biochemical Study}

There was a non statistical significant difference between the control group and garlic treated groups as regard superoxide dismutase (SOD) activities, reduced glutathione (GSH), malondialdehyde (MDA) and nitric oxide level in brain tissue (Table 4).

So the negative control group was chosen to compare with the FA treated group and formaldehyde and garlic treated group.

Mean values of SOD and GSH show high statistical significant decrease While MDA and NO level show high statistical significant increase in formaldehyde treated group when compared with control group (Table 5). 
Table 1. Sociodemographic data among different studied groups.

\begin{tabular}{|c|c|c|c|c|}
\hline & $\begin{array}{l}\text { Gross Anatomy lab workers } \\
\text { (FA-exposed ) }\end{array}$ & $\begin{array}{l}\text { Librarians } \\
\text { (control) }\end{array}$ & test & $\mathrm{p}$ value \\
\hline Age (years) & $25-50$ & $23-54$ & $0.509^{*}$ & 0.61 \\
\hline Mean \pm SD & $35 \pm 6.451$ & $36 \pm 5.972$ & & \\
\hline Duration of work (years) & $1-26$ & $1-30$ & & \\
\hline Mean \pm SD & $15.5 \pm 2.853$ & $16.5 \pm 2.601$ & $1.16^{*}$ & 0.25 \\
\hline Sex & N. (\%) & N. (\%) & & \\
\hline Male & $14(70.0)$ & $12(60.0)$ & $0.44^{* *}$ & 0.507 \\
\hline Female & $6(30.0)$ & $8(40.0)$ & & \\
\hline \multicolumn{5}{|l|}{ Marital state } \\
\hline Married & $15(75.0)$ & $12(60.0)$ & $1.03^{* *}$ & 0.31 \\
\hline Non married & $5(25.0)$ & $8(40.0)$ & & \\
\hline \multicolumn{5}{|l|}{ Education } \\
\hline Basic & $7(35.0)$ & $4(20.0)$ & $3.37^{* *}$ & 0.34 \\
\hline Secondary & $10(50.0)$ & $9(45.0)$ & & \\
\hline High & $3(15.0)$ & $5(25.0)$ & & \\
\hline Postgraduate & $0(0.0)$ & $2(10.0)$ & & \\
\hline
\end{tabular}

SD: Standard Deviation; N. (\%): Number (percent); ${ }^{*}$ student $t$ tests for quantitative variables; ${ }^{* *}$ chi square test for qualitative variables.

Table 2. Middlesex hospital questionnaire (MHQ) among studied groups.

\begin{tabular}{ccccc}
\hline & $\begin{array}{c}\text { Gross Anatomy lab workers (FA-exposed) } \\
\text { Mean } \pm \text { SD }\end{array}$ & $\begin{array}{c}\text { Librarians (control) } \\
\text { Mean } \pm \text { SD }\end{array}$ & t test & P vlue \\
\hline Free-floating anxiety & $3.95 \pm 2.11$ & $2.15 \pm 1.01$ & 3.44 & $0.001^{* *}$ \\
Phobia & $2.45 \pm 1.01$ & $2.31 \pm 1.17$ & 0.405 & 0.68 \\
obsessions & $4.9 \pm 2.55$ & $5.15 \pm 2.65$ & 0.304 & 0.76 \\
Somatization & $6.55 \pm 3.22$ & $3.95 \pm 2.01$ & 3.06 & $\mathbf{0 . 0 0 4 ^ { * }}$ \\
Depression & $5.95 \pm 2.89$ & $3.40 \pm 1.64$ & 3.43 & $\mathbf{0 . 0 0 2 ^ { * }}$ \\
Hysteria & $4.75 \pm 1.51$ & $4.28 \pm 1.44$ & 1.007 & 0.32 \\
\hline
\end{tabular}

SD: Standard Deviation; $t$ test: Student $t$ test; ${ }^{*}$ : Significant $(\mathrm{P}<0.05)^{* *}$ : Highly-significant $(\mathrm{P}<0.001)$.

Table 3. Hostility Direction and Hostility Quantity Questionnaire (HDHQ) among studied groups.

\begin{tabular}{ccccc}
\hline & $\begin{array}{c}\text { Gross Anatomy lab workers (FA-exposed) } \\
\text { Mean } \pm \text { SD }\end{array}$ & $\begin{array}{c}\text { Librarians (control) } \\
\text { Mean } \pm \text { SD }\end{array}$ & t test & P value \\
\hline Self-criticism & $4.35 \pm 1.28$ & $3.10 \pm 1.12$ & 3.29 & $\mathbf{0 . 0 0 2 ^ { * }}$ \\
Paranoid hostility & $2.7 \pm 1.06$ & $1.3 \pm 0.63$ & 5.078 & $<0.001^{* *}$ \\
Acting out & $4.65 \pm 1.85$ & $3.15 \pm 1.41$ & 2.88 & $\mathbf{0 . 0 0 6 ^ { * }}$ \\
Criticism of others & $6.25 \pm 2.11$ & $4.5 \pm 1.91$ & 2.75 & $\mathbf{0 . 0 0 9 ^ { * * }}$ \\
$\quad$ Guilt feeling & $4.15 \pm 1.48$ & $2.75 \pm 1.1$ & 3.39 & $\mathbf{0 . 0 0 2 ^ { * }}$ \\
Total hostility degree & $19.85 \pm 6.24$ & $15.65 \pm 6.66$ & 2.06 & $\mathbf{0 . 0 4 6 ^ { * }}$ \\
Direction of hostility & $-2.75 \pm 3.86$ & $0.95 \pm 5.01$ & 2.62 & $\mathbf{0 . 0 1 3 ^ { * }}$ \\
\hline
\end{tabular}

SD: Standard Deviationt; $\mathrm{t}$ test: Student $\mathrm{t}$ test; ${ }^{*}$ : Signifiant $(\mathrm{P}<0.05)$; ${ }^{* *}$ : Highly significant $(\mathrm{P}<0.001)$. 


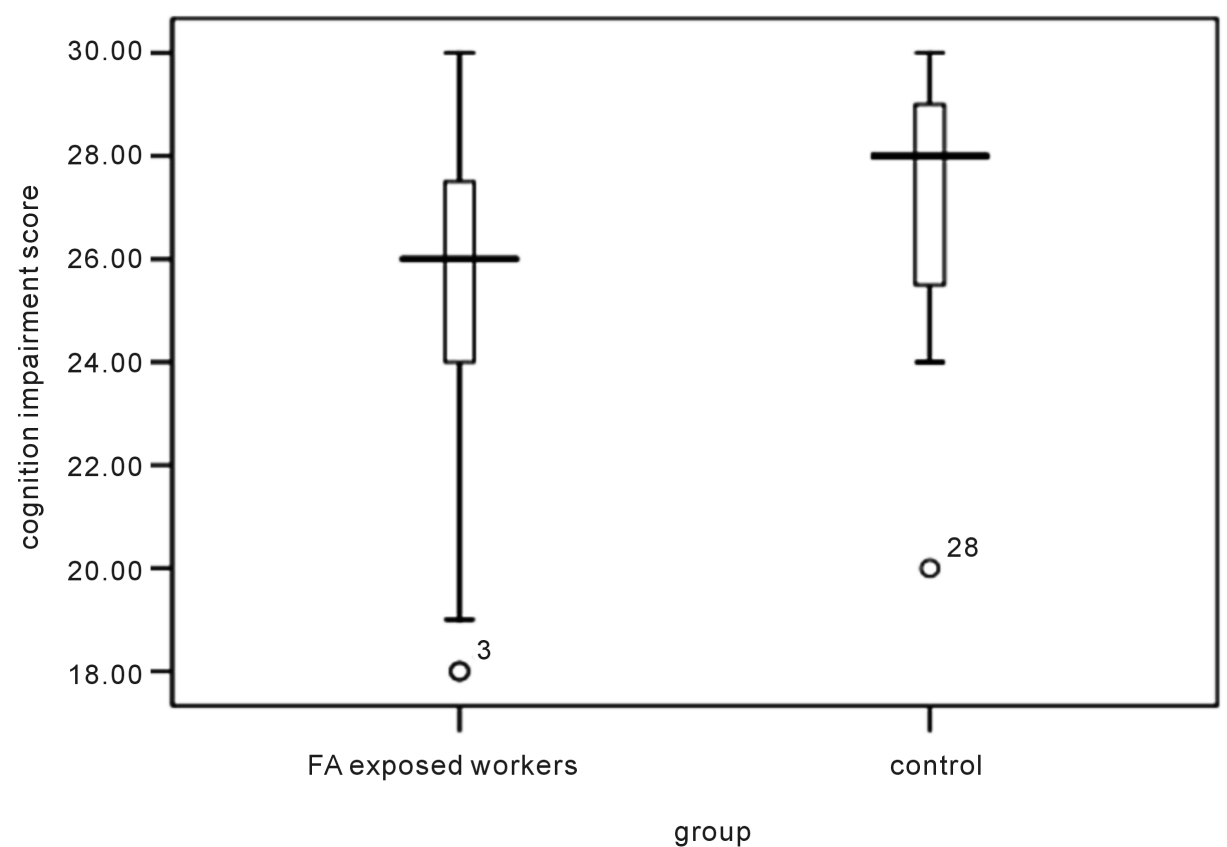

Figure 1. Box plot showing Folstein Minimental state examination among studied groups.

Table 4. Statistical comparison between the negative control and garlic treated group as regard SOD (U/L), GPx (ng/ml), MDA (mmol/l) and nitric oxide levels in brain tissues along the period of the study by $\mathrm{t}$ test.

\begin{tabular}{ccccc}
\hline Parameter in brain tissue & $\begin{array}{c}\text { Negative control group (I) } \\
\text { Mean } \pm \text { SD }\end{array}$ & $\begin{array}{c}\text { Garlic treat group (III) } \\
\text { Mean } \pm \text { SD }\end{array}$ & t test & P value \\
\hline SOD $(\mathrm{U} / \mathrm{L})$ & $64.46 \pm 5.72$ & $64.34 \pm 5.35$ & 0.048 & 0.96 \\
GPx $(\mathrm{ng} / \mathrm{ml})$ & $28 \pm 4.62$ & $27.81 \pm 4.57$ & 0.093 & 0.93 \\
MDA $(\mathrm{mmol} / \mathrm{l})$ & $98.35 \pm 8.99$ & $97.85 \pm 5.07$ & 0.15 & 0.88 \\
Nirtric oxide $(\mu \mathrm{mol} / \mathrm{g})$ & $45.84 \pm 2.08$ & $45.99 \pm 2.04$ & 0.16 & 0.87 \\
\hline
\end{tabular}

SD: Standard Deviation. Number of sacrificed rats for each group was 10 rats. $t$ test: Student $t$ test; SOD: Superoxide dismutase; GPx: Glutathione peroxidase; MDA: Malondialdehyde.

Table 5. Statistical comparison among the negative control, formaldehyde group, formaldehyde and garlic treated group as regard SOD (U/L), GPx $(\mathrm{ng} / \mathrm{ml})$, MDA $(\mathrm{mmol} / \mathrm{l})$ and nitric oxide levels in brain tissues along the period of the study by ANOVA and post hoc test.

\begin{tabular}{|c|c|c|c|c|c|}
\hline $\begin{array}{c}\text { Parameter in brain } \\
\text { tissue }\end{array}$ & $\begin{array}{l}\text { Negative control } \\
\text { group (I) } \\
\text { Mean } \pm \text { SD }\end{array}$ & $\begin{array}{l}\text { FA treated } \\
\text { group (III) } \\
\text { Mean } \pm \text { SD }\end{array}$ & $\begin{array}{c}\text { FA and Garlic treated } \\
\text { group (IV) } \\
\text { Mean } \pm \text { SD }\end{array}$ & ANOVA & $P$ value \\
\hline $\operatorname{SOD}(\mathrm{U} / \mathrm{L})$ & $64.46 \pm 5.72$ & $28.85 \pm 2.56^{\mathrm{a}}$ & $50.88 \pm 6.02^{\mathrm{a}, \mathrm{b}}$ & 128.311 & $<0.0001^{\star *}$ \\
\hline $\mathrm{GPx}(\mathrm{ng} / \mathrm{ml})$ & $28 \pm 4.62$ & $10.62 \pm 1.6^{\mathrm{a}}$ & $20.54 \pm 5.77^{\mathrm{a}, \mathrm{b}}$ & 39.873 & $<0.0001^{* *}$ \\
\hline $\mathrm{MDA}(\mathrm{mmol} / \mathrm{l})$ & $98.35 \pm 8.99$ & $402.34 \pm 4.9^{\mathrm{a}}$ & $115.48 \pm 5.18^{\mathrm{a}, \mathrm{b}}$ & 6645.477 & $<0.0001^{* *}$ \\
\hline Nirtric oxide $(\mu \mathrm{mol} / \mathrm{g})$ & $45.84 \pm 2.08$ & $109.56 \pm 3.05$ & $65.03 \pm 4.17^{\mathrm{a}, \mathrm{b}}$ & 1033.506 & $<0.0001^{* *}$ \\
\hline
\end{tabular}

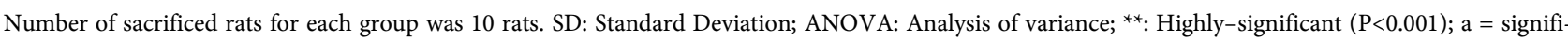
cant versus control group; $\mathrm{b}=$ significant versus formaldehyde treated group; SOD: Superoxide dismutase; GPx: Glutathione peroxidase; MDA: Malondialdehyde. 
In formaldehyde and garlic treated group SOD and GSH show high statistical significant increase while MDA and NO show high statistical significant decrease when compared with formaldehyde treated group (Table 5).

\subsubsection{Histopathological Study}

Specimen from brain of both control and garlic treated group showing few granular cells and pyramidal cells with vesicular nuclei, basophilic cytoplasm and processes. The surrounding neuropil contains nerve fibers and blood vessels (Figure 2, Figure 3).

While specimens from brain of formaldehyde treated rats' revealed histopathological changes in the brain by light microscope which revealed many distorted cells with deeply stained shrunken nuclei and cytoplasm surrounded by vacuolated pale areas. Few pyramidal cells appeared normally (Figure 4). Most of these changes were reversed in formaldehyde and garlic treated group (Figure $5)$.

\section{Discussion}

Formaldehyde is widely used chemical compound in industrial field. It's a member of the aldehyde family and one in all the simplest organic molecules. FA is taken into account as a typical indoors and outdoors waste matter [42]. The perception of FA by odor and eye irritation becomes less sensitive with time because of adaptation. This result of overexposure to formaldehyde is to alert

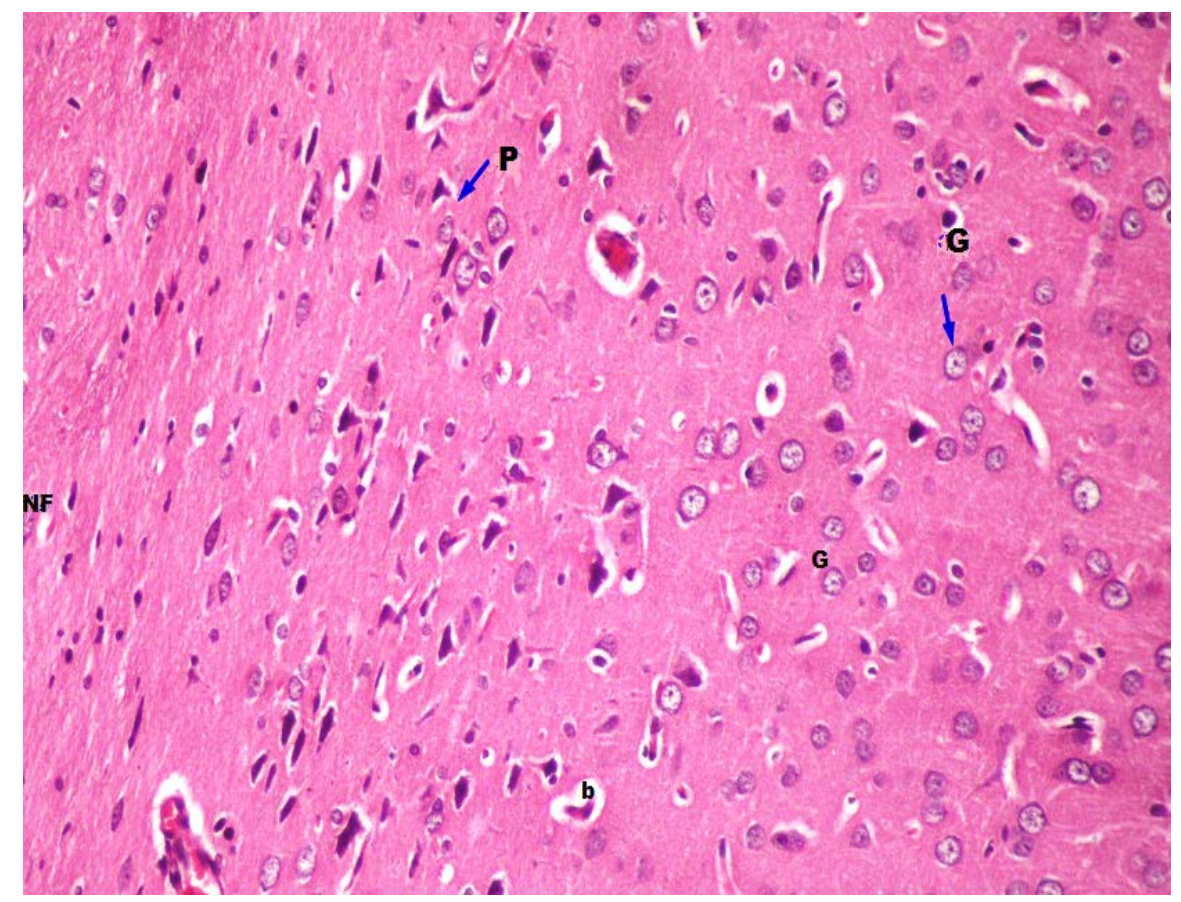

Figure 2. A photomicrograph of a section in the internal granular and internal pyramidal layers of frontal cortex of a control rat showing few granular cells (G) and pyramidal cells (P) with vesicular nuclei, basophilic cytoplasm and processes. The surrounding neuropil contains nerve fibers (NF) and blood vessels (b). ( $\mathrm{Hx}$ and $\mathrm{E} \times 400)$. 


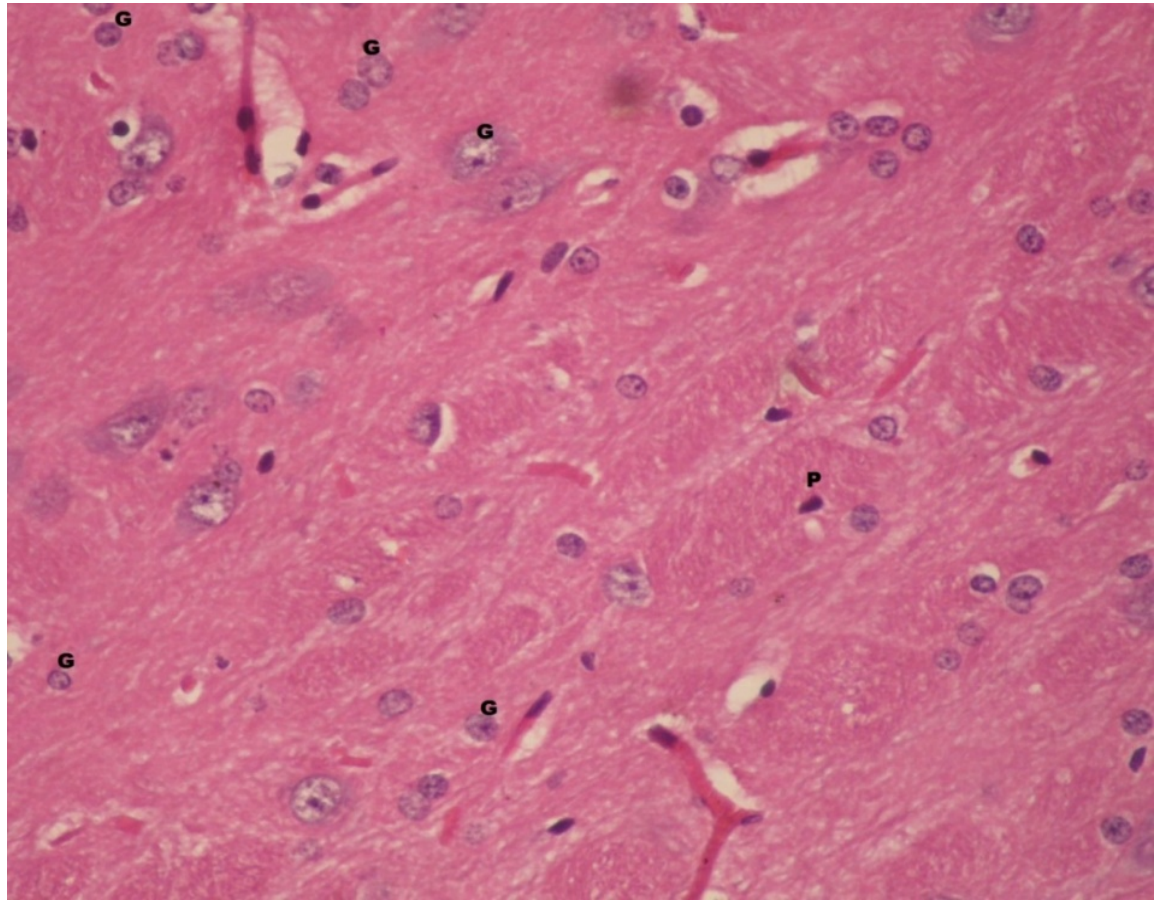

Figure 3. A photomicrograph of a section in the internal granular and internal pyramidal layers of frontal cortex of garlic treated group rat showing few granular cells (G) and pyramidal cells $(\mathrm{P})$ with vesicular nuclei, basophilic cytoplasm and processes. ( $\mathrm{Hx}$ and $\mathrm{E}$ $\times 400)$.

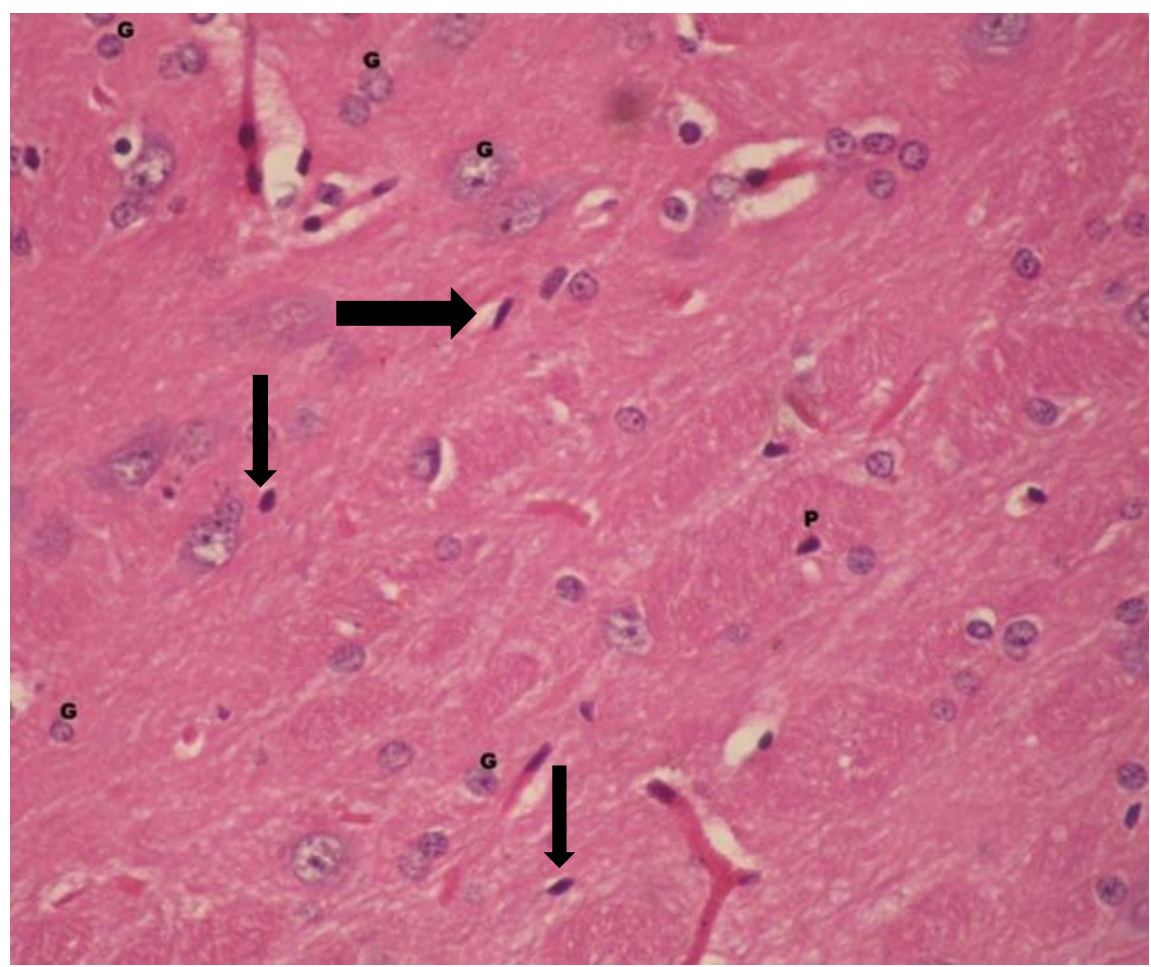

Figure 4. A photomicrograph of a section from frontal cortex of formaldehyde treated rat showing distorted cells with deeply stained shrunken nuclei and cytoplasm (arrow). Unstained areas are surrounding cells (arrow head) $(\mathrm{Hx}$ and $\mathrm{E} \times 400)$. 


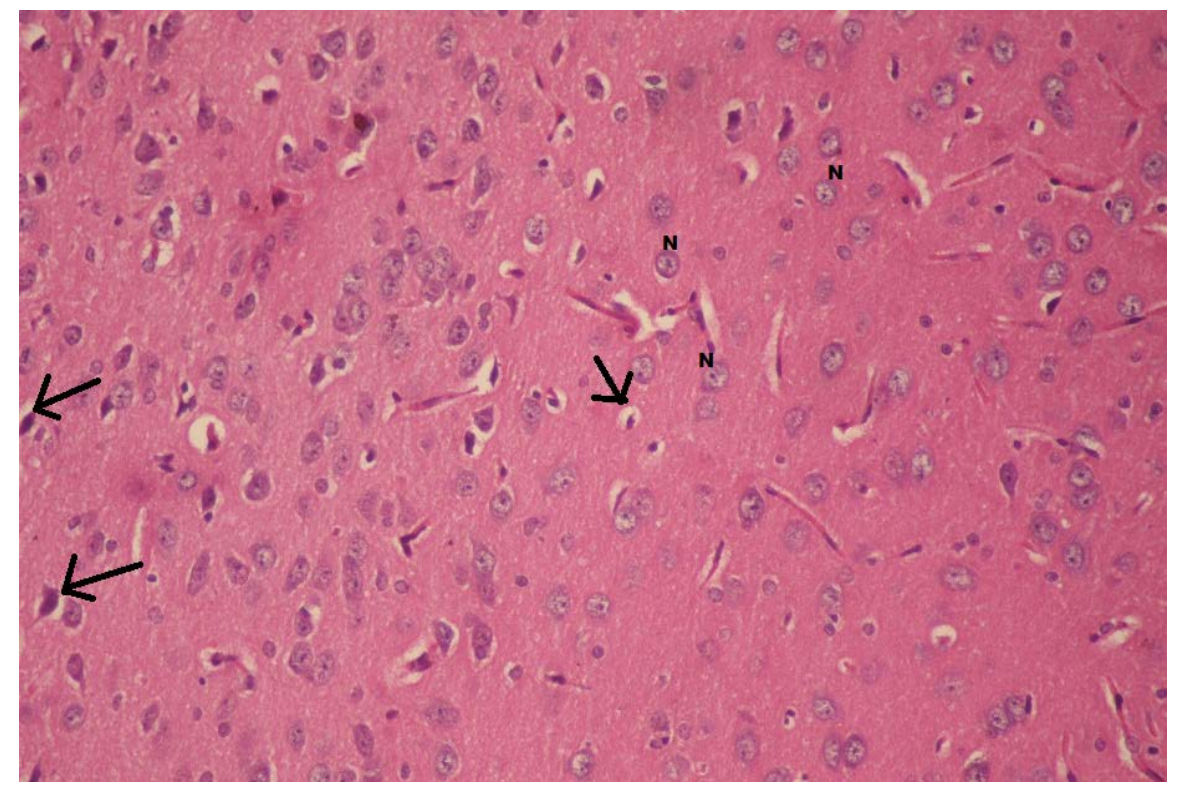

Figure 5. A photomicrograph of a section from frontal cortex of garlic and formaldehyde treated group showing that some nerve cell in the cortical layer appear normally with large vesicular nuclei $(\mathrm{N})$. Some cells appear distorted cells with deeply stained shrunken nuclei and cytoplasm (arrow) $(\mathrm{Hx}$ and $\mathrm{E} \times 400)$.

employee (him or her) to the potential threat [43]. The CNS is one of the commonest systems affected by the FA. Occupationally subject worker to FA includes anatomists, histologists, pathologists, students, and nurses working at dialysis units [22] [44].

Neurotoxicity is any effects on the structure or function of both the central and/or peripheral nervous system. The nervous system is of particular important as mature neurons are incapable of regeneration [45].

Our study is a trial to evaluate the neuropsychiatric sequel to chronic FA exposure and the role of garlic (as antioxidant) in protection from FA-induced neurotoxicity your paper.

\subsection{Clinical Study}

Both FA-exposed persons (gross anatomy Lab. workers) and control group (librarians) were matched for several factors like age, gender, educational level and marital status. Clinical assessment of both groups revealed that, the most common physical symptom reported by FA-exposed group was: easy fatigability, headache, excessive sleep, anorexia, eye irritation and excessive lacrimation, chest tightness and cough. These results came closely in agreement with those obtained by [46] [47] [48] [49], who stated that, several manifested symptoms might be related to formaldehyde exposure like lethargy, decrease in motor activity and loss of appetite.

Mini-mental state examination in the present study revealed that, FA-exposed persons were more cognitively impaired than control group. Four FA-exposed persons suffered from mild cognitive impairment (18 - 23) [50]. Epidemiological 
investigations indicate that exogenous formaldehyde exposure causes human cognitive decline [44] [51] [52]. Also, inhaled FA has been shown to cause behavioral and memory disorders in rats and has been classified as 'probable neurotoxic' [53] [54].

Tong et al. [55] stated that, exposure of normal mice to FA leads to marked memory decline.

Also, exogenous formaldehyde exposure causes human cognitive impairment and animal memory loss; furthermore many studies proved that formaldehyde at pathological levels induces $\mathrm{A} \beta$ deposition and misfolded tau protein to form globular amyloid-like aggregates [55].

Middlesex hospital questionnaire (MHQ) of studied teams had shown a statistically important distinction between the 2 teams. FA exposed team suffered from additional anxiety, somatization and depression. Epidemiological studies have shown that work-related exposure to FA leads to headaches, fatigue, anxiety, sleep disorders, and particularly cognitive disorders [44] [56]. Different concentrations of aerosolized formaldehyde lead to completely different effects on anxiety, depression-like behavior and cognition ability which can be related to alterations in hippocampal glucocorticoid receptors and brain tyrosine hydroxylase levels [57]. FA can react with the nerve proteins that referred to as neuroamines and neurotransmitters (as catecholamine) which might impair neurological system performance and may cause endocrine disruption [58]. FA inhalation might increase activity of the hypothalamic-pituitary-adrenal (HPA) axis therefore mitigate FA neurotoxicity. The recurrent exposure to low level formaldehyde alters HPA axis functioning and the release of stress hormones [59] [60]. There are several reports of malaise, headache, dyspepsia, balance and sleep disorders, and mental and memory changes because of FA exposure [44] [47].

The study of hostility within the studied teams by, Hostility Direction and Hostility quantity questionnaire, discovered that, formaldehyde-exposed cluster were additionally hostile than control cluster. The direction of hostility in formaldehyde-exposed cluster was higher toward outside than control cluster. Self-criticism, paranoid hostility, acting out hostility, criticism of others were statistically higher among formaldehyde-exposed cluster as compared to controls. The results of animal experiments reveal that inhaled formaldehyde induces abnormal behaviors, such as: aggression, depression, a decline in movement activity, and spatial memory deficits [61] [62] [63]. Formaldehyde has many effects on memory, learning, and behavior [3].

\subsection{Experimental Study}

We examined the toxic effects of exposure to FA on the brain (hippocampus and frontal cortex) of adult male albino rats and the role of garlic to minimize these effects.

Many studies have discussed the toxic effects of FA on the central nervous system [62] [64] [65]. Long-term exposure to FA can lead to irreversible neuro- 
toxicity [51]. FA has been found to cause different changes in the rat brain [66]. It was also reported that FA is capable of damaging the prefrontal cortex, including the hippocampus of rats [48] [49]. Mohamad et al. [67] stated that FA cause severe neurodegenerative changes in rats. The results of above-mentioned studies were parallel with our results, in which the histopathological study of brain (hippocampus and frontal cortex) of rats showed many distorted cells with deeply stained shrunken nuclei and cytoplasm surrounded by vacuolated pale areas. In detail, toxicological investigations have shown clear associations between formaldehyde exposure and brain tissue damage, increases cell proliferation [68] [69], DNA damage [70] [71] [72], inflammation [73] [74], changes in miRNA expression [75] and changes in gene expression signatures [74].

FA, which causes an increase in cytotoxic effects by compromising the intracellular balance, has a tendency to bind with proteins, nucleic acids and unsaturated fatty acids. These combinations lead to inflammatory reactions, allergic reactions, cytotoxicity, necrosis, mutagenesis and carcinogenesis by proteins denaturation. In addition, increase of free oxygen radicals in the FA exposed tissues and acceleration of apoptosis that cause cell death [21] [48].

In the present study, Formaldehyde showed decrease in the endogenous antioxidant system (glutathione peroxidase; GSH and superoxide dismutase; SOD). In contrast, malondialdehyde (MDA) activity, and nitric oxide (NO) levels were significantly increased.

In line with our results, numerous studies have stated that, formaldehyde (FA) exposure causes neuronal damage with oxidative stress which is considered as one of the most critical mechanism of its toxicity [76].

Chang and $\mathrm{Xu}$ [77] and Zararsiz et al. [49] suggested that, formaldehyde causes oxidative stress and lipid peroxidation. Their study showed decrease in the activity of superoxide dismutase (SOD), GSH-Px and increase in the concentration of malondialdehyde (MDA) which was consistent with our study.

The research of Zhang et al. [78]; Datta and Namasivayam [79]; Tang et al. [80] indicated that exposure to formaldehyde in experimental animals causes impairment of antioxidant enzyme activity, ROS-induced membrane lipid and protein oxidation leading to delayed apoptotic or necrotic cell death. Gouriou et al. [81] explained that, oxidative stress causes neuronal cell death by attacking cellular components. As ROS open mitochondrial permeability transition pore, resulting in mitochondrial swelling and necrosis [82].

Our study showed increase in level of NO; an explanation for this increment comes from Tang et al. [80]. They hypothesized that FA might cause neurotoxicity through the deficiency of hydrogen sulfide (H2S), which is considered as an endogenous protective antioxidant. Deficiency of H2S results from excessive generation of nitric oxide (NO) due to the inhibition of the activity of cystathionine beta synthase (CBS), a predominant $\mathrm{H} 2 \mathrm{~S}$-generating enzyme in the central nervous system. This hypothesis was studied by Li et al. [83]; Tang et al. [76]. They stated that $\mathrm{H} 2 \mathrm{~S}$ can be used to protect against FA induced neurotoxicity. 
They explained that, one of the mechanisms of FA-induced neurotoxicity involves ER stress [84]. On the other hand, and opposite to our results, the study of Mohamad [67] showed significant decrease in the levels of NO in the brain tissue of FA-treated rats, due to the effect of superoxide which reduces NO bioavailability by binding to the gaseous molecule and forming the free radical, peroxynitrite.

As a result of the above-mentioned toxic effects of FA on the brain, and that, oxidative stress is one of the proposed mechanisms, so, it was crucial to develop effective therapeutic drugs and strategies that could reverse FA induced-neurotoxicity. The use of different antioxidants as selenium [31], melatonin [49], vitamin E [85], and omega-3 essential fatty acids [86] were used to counteract FA induced neurotoxicity. Currently reliance on natural products is gaining popularity to combat various physiological threats including oxidative stress, cardiovascular complexities, cancer insurgence, and immune dysfunction. Garlic (Allium sativum) holds a unique position in history and was recognized for its therapeutic potential. Several advancements in the field of immunonutrition, physiology, and pharmacology further explored its importance as a functional food against various pathologies [34].

The effectiveness of garlic has been related to its potent antioxidant properties [87] [88] [89]. Several studies were done on the health benefits of garlic, usually stated its sulfur containing metabolites as allicin and its derivatives. Different garlic preparations are effective against health risks and used as dietary supplements similar to aged garlic extract (AGE) and garlic oil, etc. Its components will scavenge free radicals and defend membranes from injury and maintains cell integrity [34].

The present study investigated the results of fresh garlic juice, as a potent protector, on FA-induced neural injury and oxidative stress within the rat brain tissue. Bagheri et al. [90] mentioned that, garlic in several forms has protector properties. However, Imai et al. [91] estimated that, AGE exhibits anti-oxidative activities, whereas raw or heated garlic stimulates oxidization.

In our study, there was significant decrease in the levels of lipid peroxidation (LPO) in the brain tissue of FA and garlic treated rats compared to FA-treated rats. Moreover, the level of GSH, SOD, GPx decreased significantly in the garlic and FA-treated group compared to FA-treated rats. While MDA, NO were significantly increased.

The histological results of this study showed that garlic has a protective effect against FA-induced neuronal damage. The intensity of neurodegenerative changes was less in combined FA and garlic treated group than that in the FA-treated group.

Garlic extract components such as S-allyl-L-cysteine (SAC) have neuroprotective effects against reactive oxygen species (ROS) mediated neuronal cell damages [23] [92].

It is observed that aqueous garlic extract acts as an antioxidant by scavenging 
ROS, enhancing cellular antioxidant enzymes (e.g superoxide dismutase, Catalase, Glutathione peroxidase), inhibiting peroxidation of lipid and activation of oxidant induced transcription factors [23] [93] [94].

Garlic contains a number of sulfur and phenolic compounds, which is considered as an excellent antioxidant with antimicrobial action [95] [96].

Sulfur containing compounds, especially alliin and allicin are considered as the most characteristic constituents of garlic. The amino acid, alliin, is the most representative sulfur compound in fresh garlic, and is converted to allicin by alliinase enzyme when garlic is crushed [97]. Allicin, one of the main biologically active compounds derived from garlic, has various anti-oxidative and anti-inflammatory effects both in vitro and in vivo studies, allicin treatment decreased the expression levels of MDA preserved the endogenous antioxidant enzyme activities, and suppressed the expression of inflammatory cytokines [98].

Garlic juice as associate inhibitor candidate, scavenges the ROS, stimulate cellular antioxidant enzymes. These effects are due to the presence of sulfur-containing amino acids and compounds having free carboxyl $(\mathrm{C}=0)$ and amino (NH2) contents in their structures [33] [99].

\section{Conclusion}

Clinical and psychiatric profile of FA-exposed persons revealed cognitive impaired anxious and depressed persons. There were hostile persons with more hostility toward outside. These profiles of personality arouse dangerous affairs about the toxic impact of FA on persons, family, and society. Formaldehyde-induced neuronal damage, oxidative stress and lipid peroxidation in frontal and hippocampal brain tissue were minimized by addition of garlic.

\section{Recommendations}

Complete prevention of FA exposure is impossible so it is recommended to minimize exposure during Lab work by following the Safety Guidelines as regular air monitoring, maintaining high room air exhaust rates, and using personal protective equipment. Also, early detection of neurotoxic effects in worker exposed to FA and we should encourage research for both new effective prophylactic and therapeutic drugs that could reverse or alleviate FA-induced neurotoxicity.

\section{Conflict of Interest}

No conflict of interest related to this article is to declare

\section{References}

[1] Hazardous Substances Data Bank (2013) Hazardous Substances Data Bank. National Library of Medicine. http://toxnet.nlm.nih.gov/cgi-bin/sis/htmlgen?HSDB

[2] Lyapina, M., Dencheva, M., krasteva, A., Tzekova, M. and Kisselova-Yaneva, A. 
(2014) Concomitant Contact Allergy to Formaldehyde and Methacrylic Monomers in Students of Dental Medicine and Dental. International Journal of Occupational Medicine and Environmental Health, 27, 797-807. https://doi.org/10.2478/s13382-014-0314-4

[3] Tulpule, K. and Dringen, R. (2013) Formaldehyde in Brain: An Overlooked Player in Neurodegeneration? Journal of Neurochemistry, 127, 7-21. https://doi.org/10.1111/jnc.12356

[4] Mehmet, İ., İsmail, Z., Mürse, L.D., et al. (2013) Toxic Effects of Formaldehyde on the Urinary System. Turkish Journal of Urology, 39, 48-52. https://doi.org/10.5152/tud.2013.010

[5] Sasseville, D. (2004) Hypersensitivity to Preservatives. Dermatologic Therapy, 17, 251-263. https://doi.org/10.1111/j.1396-0296.2004.04028.x

[6] De Groot, A.C., Flyvholm, M.A., Lensen, G., Menne, T. and Coenraads, P.J. (2009) Formaldehyde-Releasers: Relationship to Formaldehyde Contact Allergy. Contact allergy to Formaldehyde and Inventory of Formaldehyde-Releasers. Contact Dermatitis, 61, 63-85. https://doi.org/10.1111/j.1600-0536.2009.01582.x

[7] De Groot, A., White, I.R., Flyvholm, M.A., Lensen, G. and Coenraads, P.J. (2010) Formaldehyde-Releasers in Cosmetics: Relationship to Formaldehyde Contact Allergy. Part 2. Patch Test Relationship to Formaldehyde Contact Allergy, Experimental Provocation Tests, Amount of Formaldehyde Released, and Assessment of Risk to Consumers Allergic to Formaldehyde. Contact Dermatitis, 62, 18-31. https://doi.org/10.1111/j.1600-0536.2009.01631.x

[8] Laitinen, J., Makela, M., Mikkola, J. and Huttu, I. (2010) Fire Fighting Trainers' Exposure to Carcinogenic Agents in Smoke Diving Simulators. Toxicology Letters, 192, 61-65. https://doi.org/10.1016/j.toxlet.2009.06.864

[9] Dhareshwar, S.S. and Stella, V.J. (2008) Your Prodrug Releases Formaldehyde: Should You Be Concerned? No! Journal of Pharmaceutical Sciences, 97, 4184-4193. https://doi.org/10.1002/jps.21319

[10] Chia, S.E., Ong, C.N., Foo, S.C. and Lee, H.P. (1992) Medical Student's Exposure to Formaldehyde in Gross Anatomy Dissection Laboratory. Journal of American College Health, 41, 115-119. https://doi.org/10.1080/07448481.1992.9936310

[11] Uchiyama, I. (2010) Toxicity of Formaldehyde Exposure and the Details of Its Control Measures. Kaibogaku Zasshi, 85, 29-34.

[12] Karátson, A., Buzogány, I., Wágner, G. and Rácz, L. (1991) Sclerosing Peritonitis Caused by Disinfectant in a Patient under Peritoneal Dialysis. International Urology and Nephrology, 23, 185-190. https://doi.org/10.1007/BF02549717

[13] Wong, E.Y., Ray, R., Gao, D.L., Wernli, K.J., Li, W. and Fitzgibbons, E.D. (2006) Reproductive History, Occupational Exposures, and Thyroid Cancer Risk among Women Textile Workers in Shanghai, China. International Archives of Occupational and Environmental Health, 79, 251-258. https://doi.org/10.1007/s00420-005-0036-9

[14] Yu, L.Q., Jiang, S.F., Leng, S.G., He, F.S. and Zheng, Y.X. (2005) Early Genetic Effects on Workers Occupationally Exposed to Formaldehyde. Zhonghua Yu Fang Yi Xue Za Zhi, 39, 392-395.

[15] Cheng, G., Shi, Y., Sturla, S.J., Jalas, J.R., McIntee, E.J. and Villalta, P.W. (2003) Reactions of Formaldehyde plus Acetaldehyde with Deoxyguanosine and DNA: Formation of Cyclic Deoxyguanosine Adducts and Formaldehyde Cross-Links. Chemical Research in Toxicology, 16, 145-152. https://doi.org/10.1021/tx025614r

[16] Metz, B., Kersten, G.F., Hoogerhout, P., Brugghe, H.F., Timmermans, H.A. and de 
Jong, A. (2004) Identification of Formaldehyde-Induced Modifications in Proteins: Reactions with Model Peptides. Journal of Biological Chemistry, 279, 6235-6243. https://doi.org/10.1074/jbc.M310752200

[17] Ozen, O.A., Akpolat, N., Songur, A., Kuş, I., Zararsiz, I. and Ozaçmak, V.H. (2005) Effect of Formaldehyde Inhalation on Hsp70 in Seminiferous Tubules of Rat Testes: An Immunohistochemical Study. Toxicology \& Industrial Health, 21, 249-254. https://doi.org/10.1191/0748233705th2350a

[18] Kriebel, D., Myers, D., Cheng, M., Woskie, S. and Cocanour, B. (2001) Short Term Effect of Formaldehyde on Peak Expiratory Flow and Irritant Symptoms. Archives of Environmental Health, 56, 11-18. https://doi.org/10.1080/00039890109604049

[19] Kilburn, K.H., Seidman, B.C. and Warshaw, R. (1985a) Neurobehavioral and Respiratory Symptoms of Formaldehyde and Xylene Exposure in Histology Technicians. Archives of Environmental Health, 40, 229-233. https://doi.org/10.1080/00039896.1985.10545924

[20] Kilburn, K.H., Warshaw, R., Boylen, C.T., Johnson, S.J., Seidman, B., Sinclair, R. and Takaro, T.J. (1985b) Pulmonary and Neurobehavioral Effects of Formaldehyde Exposure. Archives of Environmental Health, 40, 254-260. https://doi.org/10.1080/00039896.1985.10545928

[21] Songur, A., Sarsilmaz, M., Ozen, O.A., Sahin, S., Koken, R., Zararsiz, I. and Ilhan, N. (2008) The Effects of Inhaled Formaldehyde on Oxidant and Antioxidant Systems of Rat Cerebellum during the Postnatal Development Process. Toxicology Mechanisms and Methods, 18, 569-574. https://doi.org/10.1080/15376510701555288

[22] Songur, A., Ozen, O.A. and Sarsilmaz, M. (2010) The Toxic Effects of Formaldehyde on the Nervous System. Reviews of Environmental Contamination and Toxicology, 203, 105-118. https://doi.org/10.1007/978-1-4419-1352-4_3

[23] Massadeh, A.M., Al-Safi, S.A., Momani, I.F., Alomary, A.A., Jaradat, Q.M. and AlKofahi, A.S. (2007) Garlic (Allium sativum L.) as a Potential Antidote for Cadmium and Lead Intoxication: Cadmium and Lead Distribution and Analysis in Different Mice Organs. Biological Trace Element Research, 120, 227-234. https://doi.org/10.1007/s12011-007-8017-3

[24] El-Demerdash, F.M., Yousef, M.I. and El-Naga, N.I. (2005) Biochemical Study on the Hypoglycemic Effects of Onion and Garlic in Alloxan-Induced Diabetic Rats. Food and Chemical Toxicology, 43, 57-63. https://doi.org/10.1016/j.fct.2004.08.012

[25] Shaarawy, S.M., Tohamy, A.A., Elgendy, S.M., Elmageed, Z.Y., Bahnasy, A. and Mohamed, M.S. (2009) Protective Effects of Garlic and Silymarin on NDEAInduced Rats Hepatotoxicity. International Journal OF Biological Sciences, 5, 549-557. https://doi.org/10.7150/ijbs.5.549

[26] Folstein, M.F., Folstein, S.E. and McHugh, P.R. (1975) "Mini-Mental State". A practical Method for Grading the Cognitive State of Patients for the Clinician. Journal of Psychiatric Research, 12, 189-198. https://doi.org/10.1016/0022-3956(75)90026-6

[27] Caine, T.M., Foulds, G.A. and Hope, K. (1967) Manual of the Hostility and Direction of Hostility Questionnaire (HDHQ). University of London Press, London.

[28] El-Taib, M.A. (1984) Arabic Version for Hostility Quantity and Hostility Direction Questionnaire (H-Q-H-D).

[29] Crown, S. and Crisp, A.H. (1966) A Short Clinical Diagnostic self Rating Scale for Psychoneurotic Patients. The Middle Sex Hospital Questionnaire (MHQ). British Journal of Psychiatry, 112, 917-923. https://doi.org/10.1192/bjp.112.490.917

[30] El-Gawad, A., et al. (1972) Arabic Version for Middlesex Hospital Questionnaire 
(MHQ).

[31] Mohammadi, S. (2014) Effect of Selenium on Neurotoxicity in Adult Male Mice Exposed to Formaldehyde. Electron Physician, 6, 939-943.

[32] Mohammadi, S. (2014) Protective Effect of N-Acetyl Cysteine against Formaldehyde-Induced Neuronal Damage in Cerebellum of Mice. Pharmaceutical Sciences, 20, 61-65.

[33] Sadeghi, A., Ebrahimzadeh-Bideskan, A.F., Fazel, A. and Haghir, H. (2013) The Effect of Ascorbic Acid and Garlic Administration on Lead-Induced Neural Damage in Rat Offspring's Hippocampus. Iranian Journal of Basic Medical Sciences, 16, 157-164.

[34] Butt, M.S., Sultan, M.T., Butt, M.S. and lqbal, J. (2009) Garlic: Nature’s Protection against Physiological Threats. Critical Reviews in Food Science and Nutrition, 13, 538-551. https://doi.org/10.1080/10408390802145344

[35] Butt, M.S. and Sultan, M.T. (2009) Levels of Trans Fats in Diets Consumed in Developing Economies. Journal of AOAC International, 13, 1277-1283.

[36] Senapati, S.K., Dey, S., Dwivedi, S.K. and Swarup, D. (2001) Effect of Garlic (Allium sativum L.) Extract on Tissue Lead Level in Rats. Journal of Ethnopharmacology, 76, 229-232. https://doi.org/10.1016/S0378-8741(01)00237-9

[37] Ahmed, A.E., Gamal, I.H., Loh, J. and Abdel-Rahman, S.Z. (1991) Studies on Mechanism of Haloacetonitrile-Induced Gastrointestinal Toxicity, Interaction of $\mathrm{Di}$ bromoacetonitrile with Glutathione as Glutathiones-Transferase in Rats. Journal of Biochemical and Molecular Toxicology, 6, 115-121. https://doi.org/10.1002/jbt.2570060205

[38] Nishikimi, M., Roa, N.A. and Yogi, K. (1972) Occurrence of Superoxide Anion in the Reaction of Reduced Phenazine Methosulfate and Oxygen. Biochemical and Biophysical Research Communications, 46, 849-854. https://doi.org/10.1016/S0006-291X(72)80218-3

[39] Ohkawa, H., Ohishi, N. and Yagi, K. (1979) Assay for Lipid Peroxides in Animal Tissues by Thiobarbituric Acid Reaction. Analytical Biochemistry, 95, 351-358. https://doi.org/10.1016/0003-2697(79)90738-3

[40] Archer, S. (1993) Measurement of Nitric Oxide in Biological Models. The FASEB Journal, 7, 340-360.

[41] SPSS Inc. (2007): SPSS for Windows, Version 16.0. Chicago, SPSS Inc. http://www.unimuenster.de/imperia/md/content/ziv/service/software/spss/handbue cher/englisch/spss_brief_guide_16.0.pdf

[42] Franklin, P., Dingle, P. and Stick, S. (2000) Raised Exhaled Nitric Oxide in Healthy Children is Associated with Domestic Formaldehyde Levels. American Journal of Respiratory and Critical Care Medicine, 161, 1757-1759. https://doi.org/10.1164/ajrccm.161.5.9905061

[43] Amoore, J.E. and Hautala, E. (1983) Odor as an Aid to Chemical Safety: Odor Thresholds Compared with Threshold Limit Values and Volatilities for 214 Industrial Chemicals in Air and Water Dilution. Journal of Applied Toxicology, 3, 272-290. https://doi.org/10.1002/jat.2550030603

[44] Kilburn, K.H., Warshaw, R. and Thornton, J.C. (1987) Formaldehyde Impairs Memory, Equilibrium, and Dexterity in Histology Technicians: Effects Which Persist for Days after Exposure. Archives of Environmental Health, 42, 117-120. https://doi.org/10.1080/00039896.1987.9935806

[45] Takeuchi, Y. (2004) Health Effects from Exposure to Chronic Levels of Industrial 
Chemicals, in Environmental Toxicology and Human Health. In: Satoh, T., Ed., Encyclopedia of Life Support Systems (EOLSS), Developed under the Auspices of the UNESCO, EOLSS Publishers, Oxford. http://www.eolss.net

[46] Ozen, O.A., Songur, A., Sarsilmaz, M., Yaman, M. and Kus, I. (2003) Zinc, Copper and Iron Concentrations in Cerebral Cortex of Male Rats Exposed to Formaldehyde Inhalation. Journal of Trace Elements in Medicine and Biology, 17, 207-209. https://doi.org/10.1016/S0946-672X(03)80027-5

[47] Songur, A., Akpolat, N., Kus, I., Ozen, O.A., Zararsiz, I. and Sarsilmaz, M. (2003) The Effects of the Inhaled Formaldehyde during the Early Postnatal Period in the Hippocampus of Rats: A Morphological and Immunehistochemical Study. Neuroscience Research Communications, 33, 168-178. https://doi.org/10.1002/nrc.10093

[48] Zararsiz, I., Kus, I., Akpolat, N., Songur, A., Ogeturk, M. and Sarsilmaz, M. (2006) Protective Effects of Omega-3 Essential Fatty Acids against Formaldehyde-Induced Neuronal Damage in Prefrontal Cortex of Rats. Cell Biochemistry and Function, 24, 237-244. https://doi.org/10.1002/cbf.1204

[49] Zararsiz, I., Kus, I., Ogeturk, M., Akpolat, N., Kose, E., Meydan, S. and Sarsilmaz, M. (2007) Melatonin Prevents Formaldehyde-Induced Neurotoxicity in Prefrontal Cortex of Rats: An Immunehistochemical and Biochemical Study. Cell Biochemistry and Function, 25, 413-418. https://doi.org/10.1002/cbf.1315

[50] Mungas, D. (1991) In-Office Mental Status Testing: A Practical Guide. Geriatrics, 46, 54-58, 63, 66.

[51] Kilburn, K.H. (1994) Neurobehavioral Impairment and Seizures from Formaldehyde. Archives of Environmental Health, 49, 37-44. https://doi.org/10.1080/00039896.1994.9934412

[52] Perna, R.B., Bordini, E.J. and Deinzer-Lifrak, M. (2001) A Case of Claimed Persistent Neuropsychological Sequelae of Chronic Formaldehyde Exposure: Clinical, Psychometric, and Functional Findings. Archives of Clinical Neuropsychology, 16, 33-44. https://doi.org/10.1093/arclin/16.1.33

[53] Bedino, J.H. (2004) Formaldehyde Exposure Hazards and Health Effects: A Comprehensive Review for Embalmers. An Official Publication of the Research and Education Department. JChem Theory Comput, 650, 2633-2649.

[54] Kanter, M. (2010) Protective Effects of Nigella sativa on Formaldehyde Induced Neuronal Injury in Frontal Cortex. Tip Araştirmalari Dergisi, 8, 1-8.

[55] Tong, Z.Q., Zhang, J., Luo, W., Wang, W., Li, F., Li, H., et al. (2011) Urine formaldehyde Level Is Inversely Correlated to Mini Mental State Examination Scores in Senile Dementia. Neurobiology of Aging, 32, 31-41. https://doi.org/10.1016/j.neurobiolaging.2009.07.013

[56] Kilburn, K.H. and Warshaw, R.H. (1992) Neurobehavioral Effects of Formaldehyde and Solvents on Histology Technicians: Repeated Testing across Time. Environmental Research, 58, 134-146. https://doi.org/10.1016/S0013-9351(05)80210-5

[57] Li, Y., Song, Z., Ding, Y., Xin, Y., Wu, T. and Su, T. (2016) Effects of Formaldehyde Exposure on Anxiety-Like and Depression-Like Behavior, Cognition, Central Levels of Glucocorticoid Receptor and Tyrosine Hydroxylase in Mice. Chemosphere, 144, 2004-2012. https://doi.org/10.1016/j.chemosphere.2015.10.102

[58] Thrasher, J.D., Broughton, A. and Madison, R. (1990) Immune Activation and Auto Antibodies in Humans with Long Term Inhalation Exposure to Formaldehyde. Archive Environ Health, 45, 217-223. https://doi.org/10.1080/00039896.1990.9940805

[59] Public Review Draft (2007) Formaldehyde Reference Exposure Levels. Appendix D 
Formaldehyde.

https://archive.epa.gov/region5/teach/web/pdf/formaldehyde_summary

[60] Sorg, B.A., Bailie, T.M., Tschirgi, M.L., Li, N. and Wu, W.R. (2001) Exposure to Repeated Low-Level Formaldehyde in Rats Increases Basal Corticosterone Levels and Enhances the Corticosterone Response to Subsequent Formaldehyde. Brain Research, 898, 314-320. https://doi.org/10.1016/S0006-8993(01)02208-9

[61] Liu, Y., Ye, Z.L., Luo, H.Z., Sun, M., Li, M. and Fan, D.S. (2009) Inhalative Formaldehyde Exposure Enhances Aggressive Behavior and Disturbs Monoamines in frontal Cortex Synaptosome of Male Rats. Neuroscience Letters, 464, 113-116. https://doi.org/10.1016/j.neulet.2009.06.037

[62] Lu, Z., Li, C.M., Qiao, Y., Yan, Y. and Yang, X. (2008) Effect of Inhaled Formaldehyde on Learning and Memory of Mice. Indoor Air, 18, 77-83. https://doi.org/10.1111/j.1600-0668.2008.00524.x

[63] Usanmaz, S.E., Akarsu, E.S. and Vural, N. (2002) Neurotoxic Effect of Acute and Subacute Formaldehyde Exposures in mice. Environmental Toxicology and Pharmacology, 11, 93-100. https://doi.org/10.1016/S1382-6689(01)00109-0

[64] Ahmed, S., Tsukahara, S. and Tin Tin Win, S. (2007) Effects of Low-Level Formaldehyde Exposure on Synaptic Plasticity-Related Gene Expression in the Hippocampus of Immunized Mice. Journal of Neuroimmunology, 186, 104-111. https://doi.org/10.1016/j.jneuroim.2007.03.010

[65] Pitten, F.A., Kramer, A., Herrmann, K., Bremer, J. and Koch, S. (2000) Formaldehyde Neurotoxicity in Animal Experiments. Pathology, Research and Practice, 196, 193-198. https://doi.org/10.1016/S0344-0338(00)80100-4

[66] Aslan, H., Songur, A. and Tunc, A.T. (2006) Effects of Formaldehyde Exposure on Granule Cell Number and Volume of Dentate Gyrus: A Histopathological and Stereological Study. Brain Research, 1122, 191-200. https://doi.org/10.1016/j.brainres.2006.09.005

[67] Mohamad, A.E., Essa, T.M. and Ata, H.S. (2015) Nigella sativa Protects against Formaldehyde-Induced Neurotoxicity in the Rat Frontal Cortex. Anatomy, 9, 117-127. https://doi.org/10.2399/ana.15.018

[68] Chang, J.C., Gross, E.A., Swenberg, J.A. and Barrow, C.S. (1983) Nasal Cavity Deposition, Histopathology, and Cell Proliferation after Single or Repeated Formaldehyde Exposures in B6C3F1 Mice and F-344 Rats. Toxicology and applied pharmacology, 68, 161-176. https://doi.org/10.1016/0041-008X(83)90001-7

[69] Monticello, T.M., Miller, F.J. and Morgan, K.T. (1991) Regional Increases in Rat Nasal Epithelial Cell Proliferation Following Acute and Subchronic Inhalation of Formaldehyde. Toxicology and applied pharmacology, 111, 409-421. https://doi.org/10.1016/0041-008X(91)90246-B

[70] Lu, K., Collins, L.B., Ru, H., Bermudez, E. and Swenberg, J.A. (2010) Distribution of DNA Adducts Caused by Inhaled Formaldehyde Is Consistent with Induction of Nasal Carcinoma But Not Leukemia. Toxicological Sciences, 116, 441-445. https://doi.org/10.1093/toxsci/kfq061

[71] Lu, K., Moeller, B., Doyle-Eisele, M., McDonald, J. and Swenberg, J.A. (2011) Molecular Dosimetry of $N^{2}$-Hydroxymethyl-dG DNA Adducts in Rats Exposed to Formaldehyde. Chemical Research in Toxicology, 24, 159-161. https://doi.org/10.1021/tx1003886

[72] Moeller, B.C., Lu, K., Doyle-Eisele, M., McDonald, J., Gigliotti, A. and Swenberg, J.A. (2011) Determination of $N^{2}$-Hydroxymethyl-dG Adducts in the Nasal Epithelium and Bone Marrow of Nonhuman Primates Following ${ }^{13} \mathrm{CD}_{2}$-Formaldehyde 
Inhalation Exposure. Chemical Research in Toxicology, 24, 162-164. https://doi.org/10.1021/tx1004166

[73] Andersen, M.E., Clewell, H.J., Bermudez, E., Willson, G.A. and Thomas, R.S. (2008) Genomic Signatures and Dose-Dependent Transitions in Nasal Epithelial Responses to Inhaled Formaldehyde in the Rat. Toxicological Sciences, 105, 368-383. https://doi.org/10.1093/toxsci/kfn097

[74] Andersen, M.E., Clewell, H.J., Bermudez, E., Dodd, D.E., Willson, G.A., Campbell, J.L. and Thomas, R.S. (2010) Formaldehyde: Integrating Dosimetry, Cytotoxicity, and Genomics to Understand Dose-Dependent Transitions for an Endogenous Compound. Toxicological Sciences, 118, 716-731. https://doi.org/10.1093/toxsci/kfq303

[75] Rager, J.E., Moeller, B.C., Doyle-Eisele, M., Kracko, D., Swenberg, J.A. and Fry, R.C. (2013) Formaldehyde and Epigenetic Alterations: MicroRNA Changes in the Nasal Epithelium of Nonhuman Primates. Environmental Health Perspectives 121, 339-344. https://doi.org/10.1289/ehp.1205582

[76] Tang, X.Q., Ren, Y.K., Zhou, C.F., Yang, C.T., Gu, H.F. and He, J.Q. (2012) Hydrogen Sulfide Prevents Formaldehyde-Induced Neurotoxicity to PC12 Cells by Attenuation of Mitochondrial Dysfunction and Pro-Apoptotic Potential. Neurochemistry International, 61, 16-24. https://doi.org/10.1016/j.neuint.2012.04.011

[77] Chang, J.R. and Xu, D.Q. (2006) Effects of Formaldehyde on the Activity of Superoxide Dismutases and Glutathione Peroxidase and the Concentration of Malondialdehyde. Wei Sheng Yan Jiu, 35, 653-655.

[78] Zhang, Y., Liu, X., McHale, C., Li, R. and Zhang, L. (2013) Bone Marrow Injury Induced via Oxidative Stress in Mice by Inhalation Exposure to Formaldehyde. PLoS ONE, 8, e74974. https://doi.org/10.1371/journal.pone.0074974

[79] Datta, N.J. and Namasivayam, A. (2003) In vitro Effect of Methanol on Folate-Deficient Rat Hepatocyte. Drug Alcohol Depend, 71, 87-91. https://doi.org/10.1016/S0376-8716(03)00066-8

[80] Tang, X.Q., Fang, H.R., Zhou, C.F., Zhuang, Y.Y., Zhang, P., Gu, H.F. and Hu, B. (2013) A Novel Mechanism of Formaldehyde Neurotoxicity: Inhibition of Hydrogen Sulfide Generation by Promoting Overproduction of Nitric Oxide. PLoS ONE, 8, e54829. https://doi.org/10.1371/journal.pone.0054829

[81] Gouriou, Y., Demaurex, N., Bijlenga, P. and De Marchi, U. (2011) Mitochondrial Calcium Handling during Ischemia-Induced Cell Death in Neurons. Biochimie, 93, 2060-2067. https://doi.org/10.1016/j.biochi.2011.08.001

[82] Zhang, Y., Wang, H., Li, J., Jimenez, D.A., Levitan, E.S., Aizenman, E. and Rosenberg, P.A. (2004) Peroxynitrite-Induced Neuronal Apoptosis Is Mediated by Intracellular Zinc Release and 12-Lipoxygenase Activation. Journal of Neuroscience, 24, 10616-10627. https://doi.org/10.1523/JNEUROSCI.2469-04.2004

[83] Li, X., Zhang, K.Y., Zhang, P., Chen, L.X., Wang, L., Xie, M., Wang, C.Y. and Tang, X.Q. (2014) Hydrogen Sulfide Inhibits Formaldehyde-Induced Endoplasmic Reticulum Stress in PC12 Cells by Upregulation of SIRT-1. PLoS ONE, 28, e89856. https://doi.org/10.1371/journal.pone.0089856

[84] Luo, F.C., Zhou, J., Lv, T., Qi, L. and Wang, S.D. (2012) Induction of Endoplasmic Reticulum Stress and the Modulation of Thioredoxin-1 in Formaldehyde-Induced Neurotoxicity. Neurotoxicology, 33, 290-298. https://doi.org/10.1016/j.neuro.2012.02.004

[85] Gurel, A., Coskun, O., Armutcu, F., Kanter, M. and Ozen, O.A. (2005) Vitamin E against Oxidative Damage Caused by Formaldehyde in Frontal Cortex and Hippo- 
campus: Biochemical and Histological Studies. Journal of Chemical Neuroanatomy, 29, 173-178. https://doi.org/10.1016/j.jchemneu.2005.01.001

[86] Zararsiz, I., Meydan, S., Sarsilmaz, M., Songur, A., Ozen, O.A. and Sogut, S. (2011) Protective Effects of Omega-3 Essential Fatty Acids against Formaldehyde-Induced Cerebellar Damage in Rats. Toxicology and Industrial Health, 27, 489-495. https://doi.org/10.1177/0748233710389852

[87] Durak, I., Aytac, B., Atmaca, Y., Devrim, E., Avci, A., Erol, C. and Oral, D. (2004) Effects of Garlic Extract Consumption on Plasma and Erythrocyte Antioxidant Parameters in Atherosclerotic Patients. Life Sciences, 75, 1959-1966. https://doi.org/10.1016/j.lfs.2004.04.015

[88] Durak, I., Kavutcu, M., Aytac, B., Avci, A., Devrim, E., Ozbek, H. and Ozturk, H.S. (2004) Effects of Garlic Extract Consumption on Blood Lipid and Oxidant/Antioxidant Parameters in Humans with High Blood Cholesterol. Journal of Nutritional Biochemistry, 15, 373-377. https://doi.org/10.1016/j.jnutbio.2004.01.005

[89] Ichikawa, M., Ryu, K., Yoshida, J., Ide, N., Yoshida, S., Sasaoka, T. and Sumi, S. (2002) Antioxidant Effects of Tetrahydro-Beta-Carboline Derivatives Identified in Aged Garlic Extract. BioFactors, 16, 57-72. https://doi.org/10.1002/biof.5520160302

[90] Bagheri, F., Gol, A., Dabiri, S. and Javadi, A. (2011) Preventive Effect of Garlic Juice on Renal Reperfusion Injury. Iranian Journal of Kidney Diseases, 5, 194-200.

[91] Imai, J., Ide, N., Nagae, S., Moriguchi, T., Matsuura, H. and Itakura, Y. (1994) Antioxidant and Radical Scavenging Effects of Aged Garlic Extract and Its Constituents. Planta Medica, 60, 417-420. https://doi.org/10.1055/s-2006-959522

[92] Ray, B., Chauhan, N.B. and Lahiri, D.K. (2011) Oxidative Insults to Neurons and Synapse Are Prevented by Aged Garlic Extract and S-Allyl- ${ }_{L}$-Cysteine Treatment in the Neuronal Culture and APP-Tg Mouse Model. Journal of Neurochemistry, 117, 388-402. https://doi.org/10.1111/j.1471-4159.2010.07145.X

[93] Senapati, S.K., Dey, S. and Dwivedi, S.K. (2001) Defect of Garlic (Allium sativum L.) Extract on Tissue Lead Level in Rats. Journal of Ethnopharmacology, 76, 229-232. https://doi.org/10.1016/S0378-8741(01)00237-9

[94] Shahsavani, D., Baghshani, H. and Alishahi, E. (2011) Efficacy of Allicin in Decreasing Lead $(\mathrm{Pb})$ Accumulation in Selected Tissues of Lead-Exposed Common Carp (Cyprinuscarpio). Biological Trace Element Research, 142, 572-580. https://doi.org/10.1007/s12011-010-8801-3

[95] Corzo-Martinez, M., Corzo, N. and Villamiel, M. (2007) Biological Properties of Onions and Garlic. Trends in Food Science \& Technology, 18, 609-625.

[96] Lanzotti, V. (2006) The Analysis of Onion and Garlic. Journal of Chromatography $A, 1112,3-22$. https://doi.org/10.1016/j.chroma.2005.12.016

[97] Itakura, Y., Ichikawa, M., Mori, Y., Okino, R., Udayama, M. and Morita, T. (2001) How to Distinguish Garlic from the Other Allium Vegetables. Journal of Nutrition, 131, 963S-967S.

[98] Chen, W., Qi, J., Feng, F., Wang, M.D., Bao, G., Wang, T., Xiang, M. and Xie, W.F. (2014) Neuroprotective Effect of Allicin against Traumatic Brain Injury via Akt/Endothelial Nitric Oxide Synthase Pathway-Mediated Anti-Inflammatory and Anti-Oxidative Activities. Neurochemistry International, 68, 28-37. https://doi.org/10.1016/j.neuint.2014.01.015

[99] Ataei, M.L. and Ebrahimzadeh-Bideskan, A.R. (2014) The Effects of Nano-Silver and Garlic Administration during Pregnancy on Neuron Apoptosis in Rat Offspring Hippocampus. Iranian Journal of Basic Medical Sciences, 17, 411-418. 